\title{
Ranking the Suitability of Sub-watersheds for Ponding-Based Methods of Managed Aquifer Recharge in Lower Yom River Basin, Thailand
}

\author{
Kriengsak Srisuk ${ }^{1}$, Sumrit Chusanatus ${ }^{2}$, Sitisak Munyou ${ }^{2}$, Laa Archwichai ${ }^{1}$, Kewaree Pholkern $^{1}$ and \\ Penlada Boonsongka ${ }^{1}$ \\ 1. Groundwater Research Center, Faculty of Technology, Khon Kaen University, Khon Kaen 40002, Thailand \\ 2. Department of Groundwater Resources, Ministry of Natural Resources and Environment, Bangkok 10900, Thailand
}

\begin{abstract}
The study area is located in the Lower Yom River Basin covering an area of about $970 \mathrm{~km}^{2}$ in the lower part of Northern Thailand, which is underlain by sequences of unconsolidated alluvial deposits derived from the Yom and Nan River floodplains. Groundwater has been heavily exploited largely for agriculture from the shallow gravel, sand and silt aquifer in the basin. Drastically declining water levels, up to $10 \mathrm{~m}$ in some areas, has been observed within the past decade, creating difficulties with lift irrigation for the local farmers. Therefore, the Department of Groundwater Resources, Thailand, considers that groundwater artificial recharge may be useful for recovering the static water levels within the most hydrogeological suitable areas. The objective of the paper is to rank the suitability of sub-watershed in the Lower Yom River Basin for conducting a pilot-scale testing of MAR (managed aquifer recharge) by ponding system. Hydrogeological and non-hydrogeological parameters were used to formulate the site selection criteria. Boolean logic and Fuzzy logic were used for delineating the 19 sub-watersheds in the Lan Ba watershed. Detailed hydrogeological investigations were conducted in the 10 most prospective sub-watersheds. Of these, the Nong Na 3 sub-watershed covering an area of about 500 hectares was determined to be the most appropriate site for the MAR pilot construction and testing.
\end{abstract}

Key words: MAR, ponding system, Boolean logic, Fuzzy logic, suitability of sub-watersheds, Lower Yom River Basin.

\section{Introduction}

Extensive use of shallow groundwater for rice growing in the Lower Northern River Basin of Thailand has caused groundwater levels to decline from $1 \mathrm{~m}$ to $2 \mathrm{~m}$ below ground surface in previous decades to $7-10 \mathrm{~m}$ at the present time [1], thereby creating difficulties with lift irrigation for the local farmers. Effective management of aquifer recharge is becoming and increasingly recognized in Thailand to be an important water resource management strategy. Artificial recharge is an effective technique for the restoration and augmentation of groundwater resources [2, 3]. Ponding systems may be one of the simplest and cheapest methods of artificial recharge

Corresponding author: Kriengsak Srisuk, associate professor, research field: hydrogeology. E-mail: kriengsk@kku.ac.th.
$[4,5]$, and is proposed to be applied to raise the groundwater levels within the unconfined aquifers across the area. The objective of the paper is to rank the suitability of sub-watersheds in the Lower Yom River Basin for conducting a pilot-scale testing of MAR (managed aquifer recharge) by ponding system based on hydrogeological and non-hydrogeological factors. The study area is located in the Lower Yom River Basin in Thailand covering an area of about 970 $\mathrm{km}^{2}$ in the administrative areas of Bangrakham District, Pitsanulok Province, and Samngam and Vachira Baramee Districts, Pichit Province (Fig. 1). This area has topographic elevations that vary from 34 $\mathrm{m}$ to $54 \mathrm{~m}$ above mean sea level. The Lower Yom River Basin consists of 13 watersheds (Fig. 1) and has a tropical monsoon climate with an annual average temperature about $28{ }^{\circ} \mathrm{C}$, annual rainfall of about 1,200 


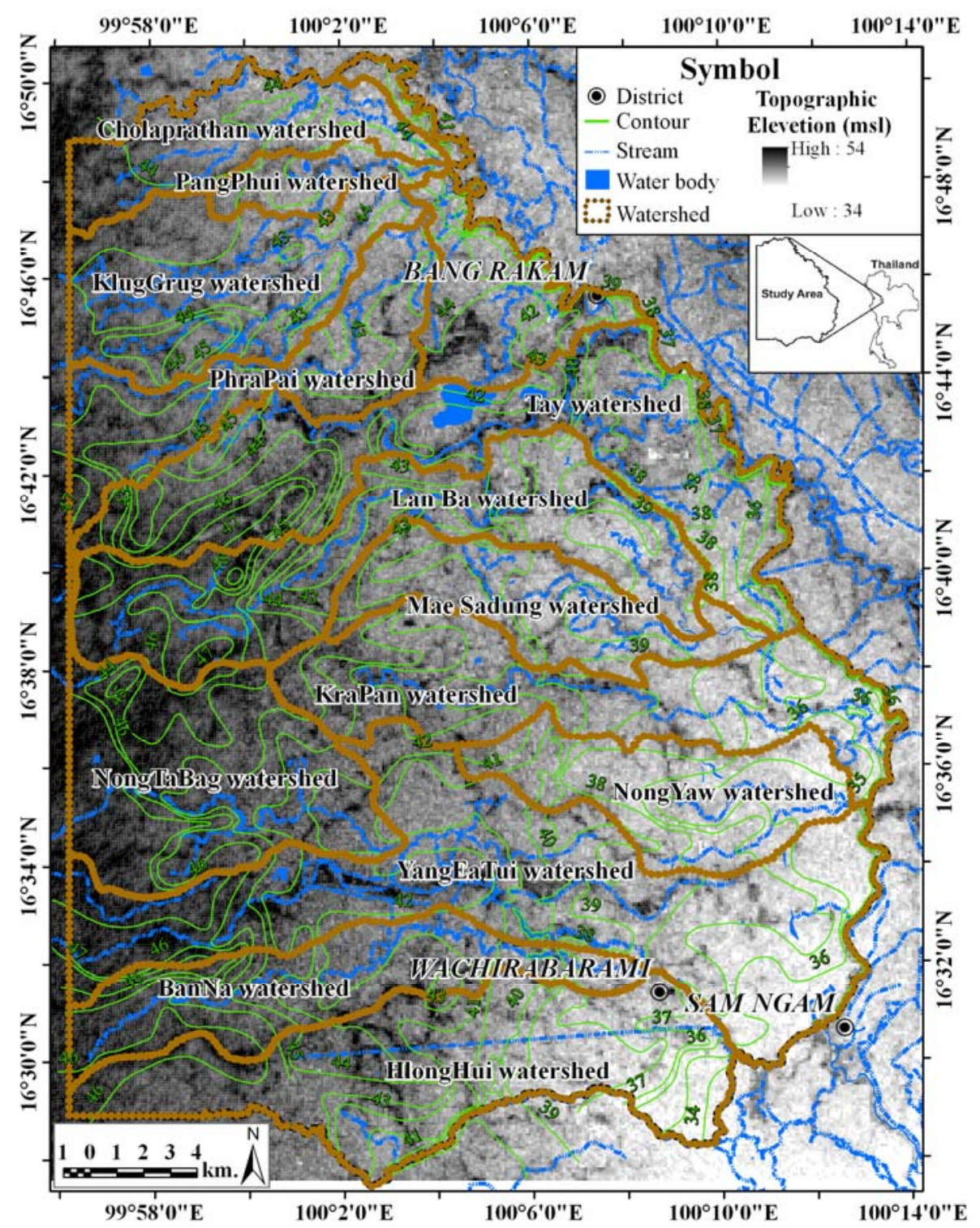

Fig. 1 The Lower Yom River Basin with 13 watersheds.

$\mathrm{mm}$ and annual evaporation of about 1,350 $\mathrm{mm}$ [6]. Groundwater-based irrigation of rice paddy is a dominant land use for the largely agrarian economy in the region. Paddy field occupies more than $70 \%$ of the area [7]. Agricultural well densities vary from 0 to more than 15 well $/ \mathrm{km}^{2}$ as shown in Fig. 2. The high well density area was observed in the central region. The Yom River is the main river in the region and flows from north to the south. The Lower Yom River Basin is underlain by alluvial fans, floodplain deposits, and channel and natural levee deposits. Alluvial fan deposits consist of gravel, sand, silt and clay.
Floodplain deposits consist mainly of clays and silts. Channel and natural levee deposits are composed of sands, silts and clays (Fig. 3). The distributions of thicknesses of clay layer or depths to the first aquifer vary from 0 to more than $15 \mathrm{~m}$ as shown in Fig. 2 .

\section{Methodology}

Selection of suitable sub-watersheds was based on both hydrogeological and non-hydrogeological parameters. The hydrogeological parameters include depth to the first aquifer, agricultural well density and aquifer thickness. The non-hydrogeological parameters 


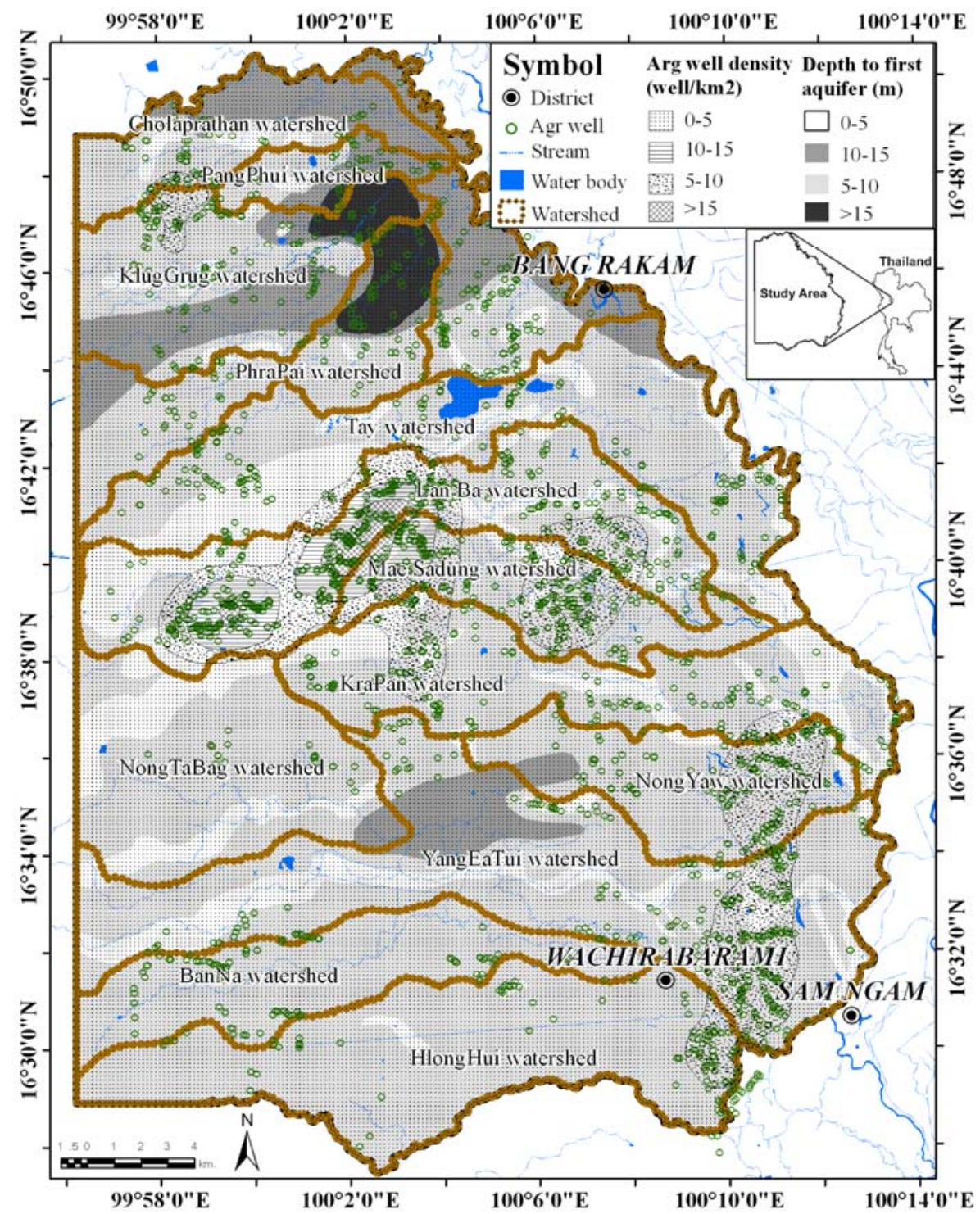

Fig. 2 Distribution of depths to the first aquifer and agricultural well density.

include distance to available water source, land availability and site accessibility, access to power supply, and land use. These data sets were compiled from several information sources as well as from field investigations during the years 2010-2011. A series of derivative maps was produced and analyzed by using the Overlay Technique. The site rating (scoring, weighting and classifying) and ranking were performed by using the Boolean and Fuzzy logic techniques [8-12]. The Boolean logic consists of "AND" and "OR" operators. Based upon set theory, whereby the "AND" operator yields the logical intersection of the two data sets, while the "OR" operator obtains the logical union of the two data sets. In classical set theory, the score of a set must be defined as either 1 or 0 [13]. The score of the Fuzzy set, however, is expressed on a continuous scale from 1 (full score) to 0 (full non-score). In contrast to Boolean logic, no certainty exists in Fuzzy logic. Therefore, no particular area is definitely satisfactory or unsatisfactory for MAR [12].

The selection of appropriate sub-watershed is divided into three steps, namely:

(1) Selecting the appropriate watershed from the 


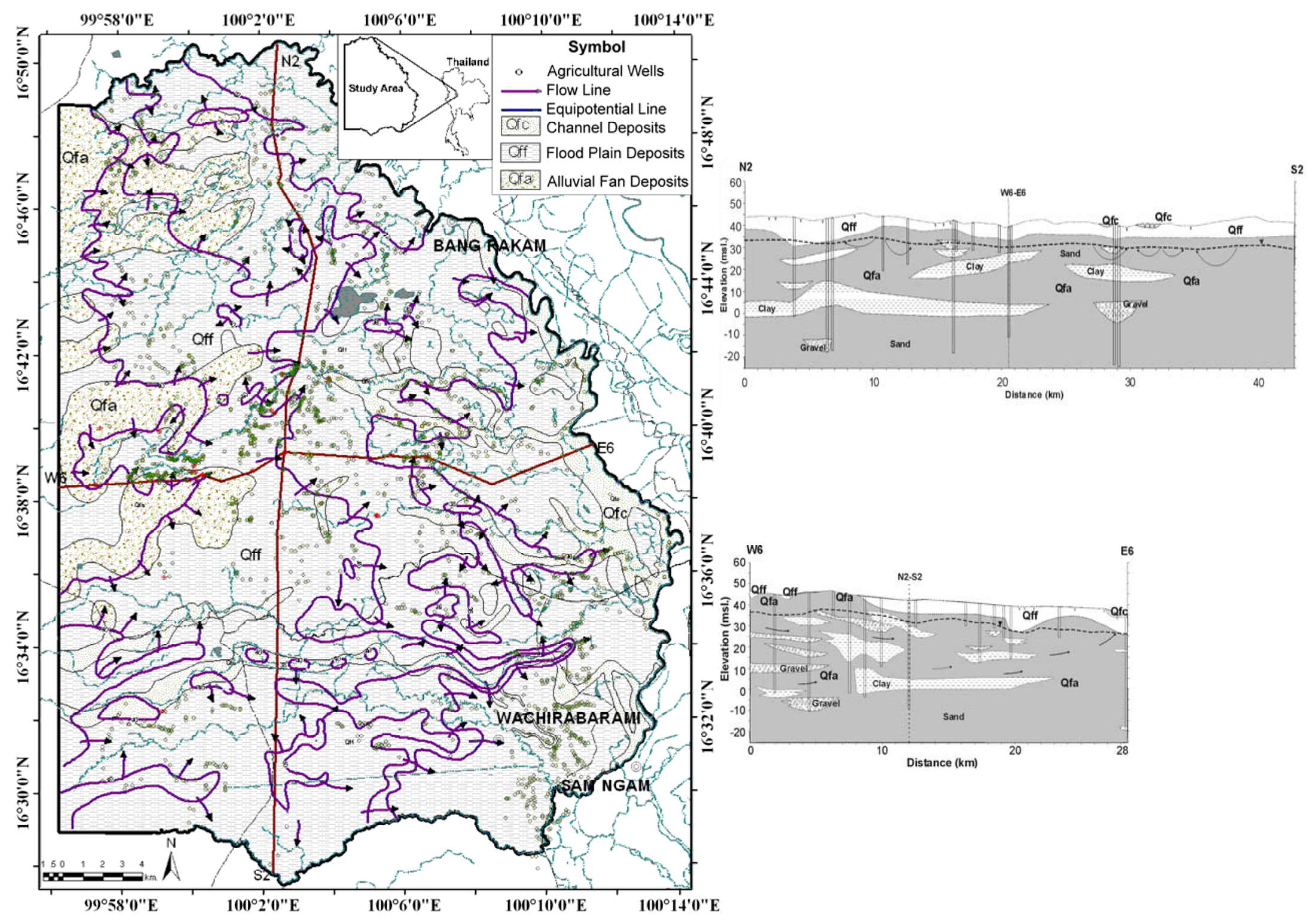

Fig. 3 Hydrogeological map and hydrogeological cross sections. 

Lower Yom River Basin, Thailand

existing 13 watersheds (from Lower Yom River Basin, Fig. 1) by considering two selection criteria. These include: (i) depth to the first aquifer (ground surface in some areas cover with thin to thick clay layer, thick clay layer increases pond construction cost and less stability of pond walls); and (ii) agricultural well density (high well density causes high decline in groundwater level). Depth to the first aquifer was derived from the hydrogeological map of a scale 1:50,000, which was interpreted from existing groundwater well logs together with project piezometers and hand augered bore hole logs. Agricultural well density was determined by using the ArcGIS software. The depth to the first aquifer and agricultural well density were anylized by GIS (Geographic Information System) with Boolean logic. The acceptable ranges of parameters were identified as shown in Table 1 . The acceptable range of depth to the first aquifer of less than $5 \mathrm{~m}$ was initially identified based on a pond construction cost and the stability of pond banks. An interval of well density was selected based on field observation and sub-watershed mapping scale. The drastically decline of groundwater levels in agricultural wells were observed in the areas with more than five active agricultural well $/ \mathrm{km}^{2}$. Thus, 5 well $/ \mathrm{km}^{2}$ is acceptable range. The appropriate watershed can be selected by overlaying of appropriate areas and watershed boundaries;

(2) From step (1), the most appropriate watersheds were divided into several sub-watersheds which were preliminarily identified based on Boolean logic as tabulated in Table 2. The sub-watershed areas with a depth to the first aquifer of less than $3 \mathrm{~m}$ were identified for suitable pond bank stability and pond construction cost. Agricultural well density was considered and mapped by number of the wells in individual sub-watershed. The areas with the number of well more than 5 wells were identified. Non-hydrogeological parameters such as distance to available surface water source, land availability and site accessibility were also taken into consideration in this step. Distance to available surface water source for recharge should be close to ponding recharge site as much as possible to save the construction cost. The analysis suggested that acceptable distance was less than $1,500 \mathrm{~m}$ from the pond. Land availability and site accessibility were also important parameters for construction of the system. The selected sub-watersheds passed all the above mentioned parameters;

(3) The sub-watersheds obtained from step (2) were rating and ranking by using Fuzzy logic. Classification, scoring of the Fuzzy set and weighting of parameters were assigned based on the collected field evidences and detailed field works (Table 3). Additional three parameters in Table 3: aquifer thickness, access to the power supply and land use, was considered in this step. Aquifer thickness is directly related to recharge potential and rising water table. Other two parameters of access to the power supply and land use were also important for construction cost and monitoring system.

\section{Results and Discussion}

Lan $\mathrm{Ba}$ watershed (Fig. 4) is the most suitable watershed of all 13 existing watersheds in the Lower Yom River Basin, for MAR. Lan Ba watershed passed all hydrogeological parameters listed in Table 1.

From hydrogeological investigation, it was found that the Lan $\mathrm{Ba}$ watershed comprises of 19 sub-watersheds, as displayed in Fig. 5. The parameters

Table 1 Acceptable ranges of parameters for selection of the appropriate watershed in the Lower Yom River Basin.

\begin{tabular}{ll}
\hline Parameter & Acceptable ranges \\
\hline Depth to the first aquifer $(\mathrm{m})$ & $0-5$ \\
Agricultural well density $\left(\right.$ well $\left./ \mathrm{km}^{2}\right)$ & $>5$ \\
\hline
\end{tabular}

Table 2 Acceptable ranges of parameters for preliminary selection of the appropriate sub-watershed.

\begin{tabular}{ll}
\hline Parameter & Acceptable ranges \\
\hline Depth to the first aquifer (m) & $<3$ \\
$\begin{array}{l}\text { Number of agricultural well (well) } \\
\text { Distance to available surface water }\end{array}$ & $<5$ \\
source for recharge) (m) & $<1,500$ \\
Land availability and site accessibility & Easy \\
\hline
\end{tabular}


Ranking the Suitability of Sub-watersheds for Ponding-Based Methods of Managed Aquifer Recharge in 163 Lower Yom River Basin, Thailand

Table 3 Selection criteria for the most appropriate sub-watershed in Fuzzy logic.

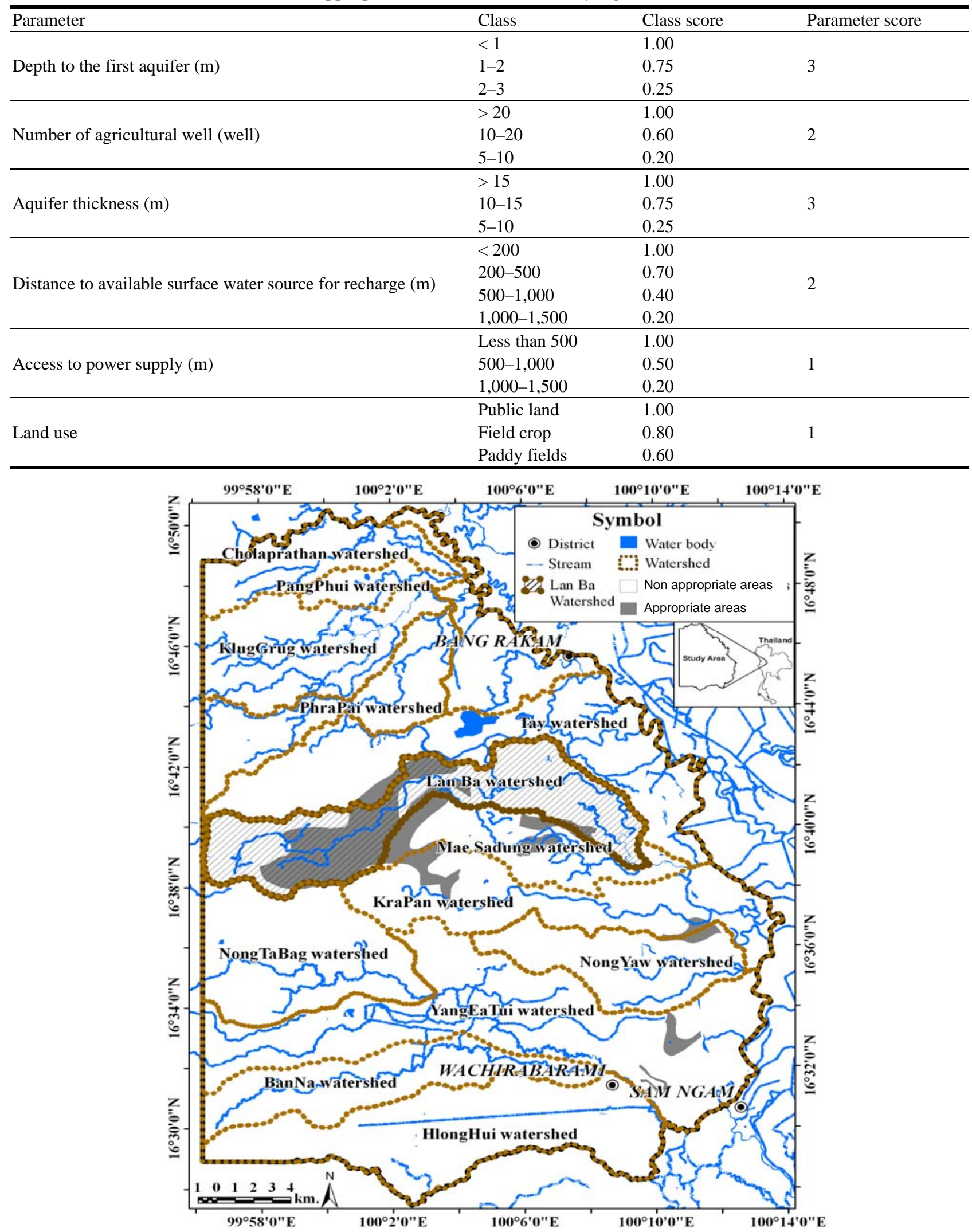

Fig. 4 Appropriate watersheds for MAR. 
and the scoring result of the 19 sub-watersheds are shown in Table 4. Ten sub-watersheds with the highest score were selected for further detailed scoring. These selected sub-watersheds include BK1, BK2, DKK1, NM2, NN1, NN2, NN3, PK1, SS2, TC1 and TC2.
The results of the detailed scoring were shown in Table 5. NN3 (Nong Na 3) sub-watershed is the most appropriate site for the MAR Pilot test construction. Nong Na 3 sub-watershed (Fig. 6) is located in Nong Na Village, Bangrakham District, Pitsanulok Province. It covers an area of about 500 hectares. Paddy field

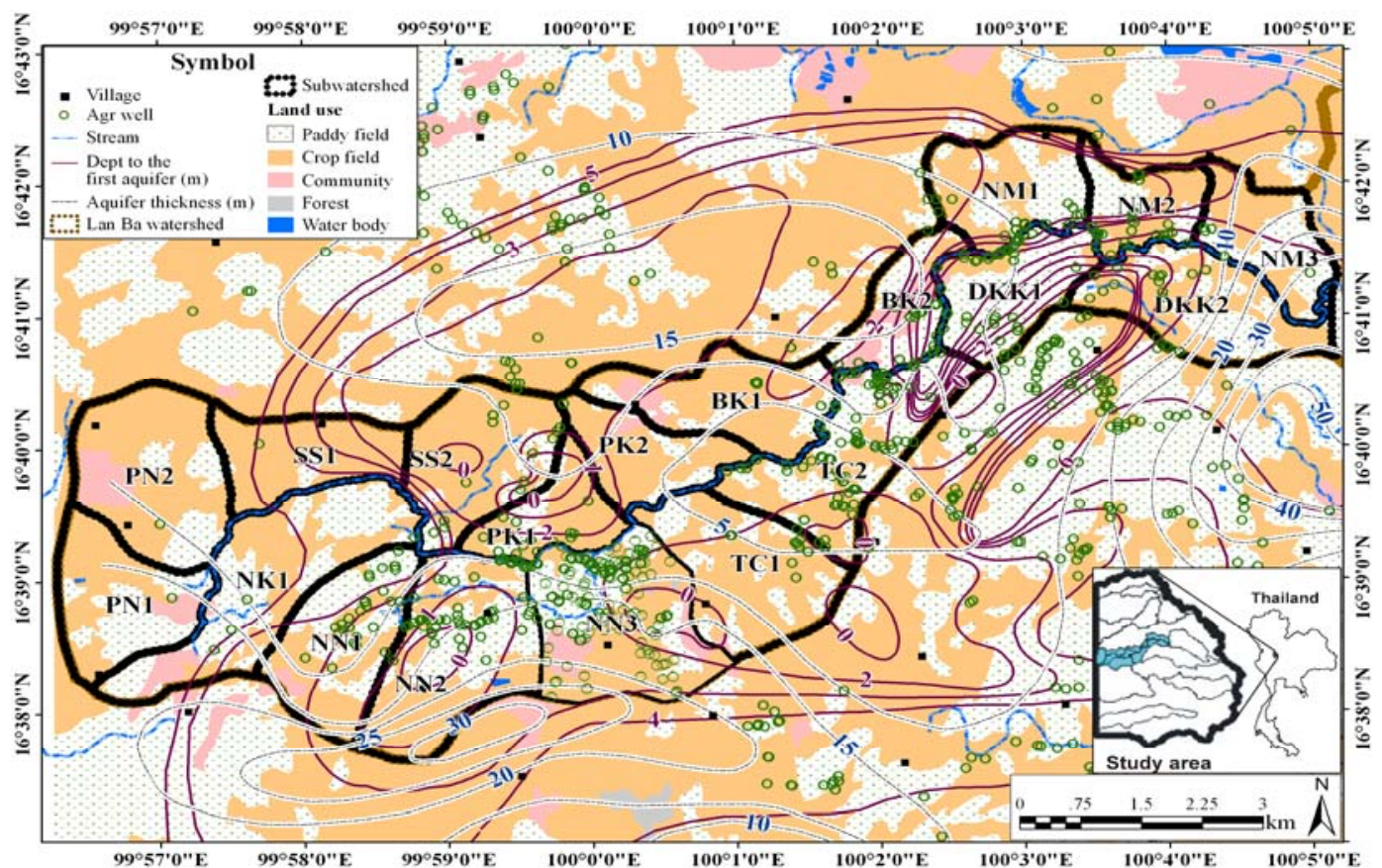

Fig. 5 Sub-watershed in the Lan Ba watershed.

Table 4 Scoring of the subwaersheds in Lan Ba watershed based on selection criteria.

\begin{tabular}{llrrrll}
\hline No & Sub-watershed & \multicolumn{1}{l}{ I } & II & III & IV & Score \\
\hline 1 & BK1 & 2 & 4 & 1,000 & Easy & 3 \\
2 & BK2 & $2-3$ & 17 & 700 & Easy & 4 \\
3 & DKK1 & $2-3$ & 44 & 1,000 & Easy & 4 \\
4 & DKK2 & $2-3$ & 17 & 200 & Difficult & 3 \\
5 & NK1 & $4-5$ & 3 & 100 & Easy & 2 \\
6 & NM1 & $3-4$ & 17 & 800 & Difficult & 3 \\
7 & NM2 & 3 & 23 & 500 & Easy & 4 \\
8 & NM3 & 6 & 5 & 500 & Easy & 3 \\
9 & NN1 & 3 & 27 & 1,000 & Easy & 4 \\
10 & NN2 & $0-1$ & 64 & 700 & Easy & 4 \\
11 & NN3 & $0-3$ & 67 & 50 & Easy & 4 \\
12 & PK1 & $0-1$ & 16 & 700 & Easy & 4 \\
13 & PK2 & $1-2$ & 1 & 1,300 & Easy & 3 \\
14 & PN1 & $5-6$ & 1 & 500 & Easy & 2 \\
15 & PN2 & $5-6$ & 1 & 1,200 & Easy & 2 \\
16 & SS1 & $3-4$ & 1 & 800 & Easy & 3 \\
17 & SS2 & $0-1$ & 13 & 400 & Easy & 4 \\
18 & TC1 & 2 & 9 & 1,200 & Easy & 4 \\
19 & TC2 & 2 & 110 & 200 & Easy & 4 \\
\hline
\end{tabular}

I = Depth to the first aquifer (m); II = number of agricultural well (well); III = distance to available surface water source (m); and IV $=$ land availability and site accessibility. 
Ranking the Suitability of Sub-watersheds for Ponding-Based Methods of Managed Aquifer Recharge in 165 Lower Yom River Basin, Thailand

Table 5 Data and scoring for detailed selection of the appropriate sub-watersheds in Lan Ba watershed.

\begin{tabular}{lllllllll}
\hline \multirow{2}{*}{ No } & \multirow{2}{*}{ Sub-watershed } & \multicolumn{7}{c}{ Data (scores are in italic) } \\
\cline { 3 - 8 } & I & II & III & IV & V & VI & Total score \\
\hline 1 & BK2 & $2-3(2.25)$ & $17(1.2)$ & $10-15(3.0)$ & $700(0.8)$ & $500(1.0)$ & P $(0.8)$ & $(9.05)$ \\
2 & DKK1 & $2-3(2.25)$ & $44(2.0)$ & $10(2.1)$ & $1,000(0.8)$ & $600(0.5)$ & C $(0.8)$ & $(8.45)$ \\
3 & NM2 & $3(0.75)$ & $23(2.0)$ & $10(2.1)$ & $500(1.4)$ & $1,200(0.2)$ & C $(0.8)$ & $(7.25)$ \\
4 & NN1 & $3(0.75)$ & $27(2.0)$ & $10-15(3.0)$ & $1,000(1.4)$ & $500(0.5)$ & C $(0.8)$ & $(8.45)$ \\
5 & NN2 & $0-1(3.0)$ & $64(2.0)$ & $15-20(3.0)$ & $700(0.8)$ & $500(0.5)$ & C (0.8) & $(10.10)$ \\
6 & NN3 & $0-3(2.25)$ & $67(2.0)$ & $15-20(3.0)$ & $50(2.0)$ & $300(1.0)$ & C \& P (0.8) & $(11.05)$ \\
7 & PK1 & $0-1(3.0)$ & $16(1.2)$ & $10(2.1)$ & $700(0.8)$ & $700(0.5)$ & C $(0.8)$ & $(8.40)$ \\
8 & SS2 & $0-1(3.0)$ & $13(1.2)$ & $10(2.1)$ & $400(1.4)$ & $700(0.5)$ & P (0.6) & $(8.80)$ \\
9 & TC1 & $2(2.25)$ & $9(0.4)$ & $5-10(0.9)$ & $1,200(0.4)$ & $800(0.5)$ & P (0.6) & $(5.05)$ \\
10 & TC2 & $2(2.25)$ & $110(2.0)$ & $5-10(2.1)$ & $200(2.0)$ & $700(0.5)$ & P (0.6) & $(9.45)$
\end{tabular}

I = depth to the first aquifer (m); II = number of agricultural well (well); III = aquifer thickness (m); IV = distance to available surface water source (m); V = access to power supply (m); and IV = land use.

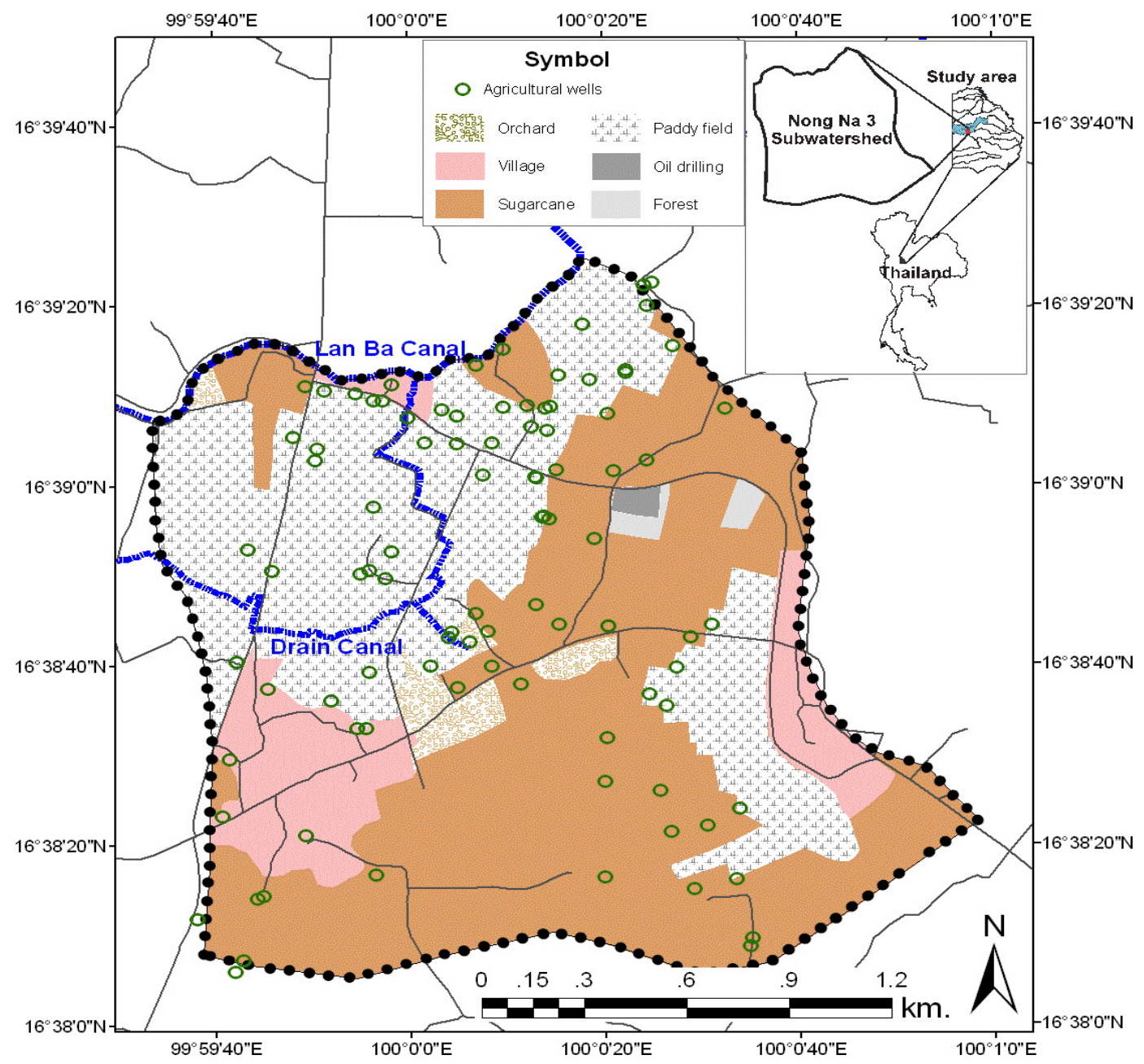

Fig. 6 Nong Na 3 sub-watershed.

and sugar cane plots are the main land uses and occupy more than $85 \%$ of the area. Surface run-off and existing creeks within the Nong $\mathrm{Na}$ area flows through the area to the Lan Ba stream located in the northern region. In this area, there are about 90 agricultural wells that have been pumping 
groundwater from the shallow aquifer (10-15 m below the ground surface). The high well density zone is located in the northern region near the Lan Ba stream. Therefore, more detailed hydrogeological investigations were conducted within the Nong $\mathrm{Na} 3$ sub-watershed in order to locate the final construction site for the MAR pilot project.

\section{Conclusions}

Diverse and complex arrays of criteria for determining the suitability of areas for MAR have been integrated and quantitatively evaluated during this study to identify the most propective watershed, and ultimately select the best sub-watersheds for MAR pilot test. Field investigations combined with GIS analyses offer a useful method in delineating the detailed study areas for ponding-based methods of MAR. Moreover, this simple technique described here can also be adapted and employed to other regions, as well as to determining the suitability of other MAR techniques, such as trenching, roof-runoff rainwater harvesting, recharge weir, and ASR (aquifer storage and recovery) for the future studies.

\section{Acknowledgement}

The authors would like to thank the Department of Groundwater Resources, Ministry of Natural Resources and Environment, Thailand for providing financial support to the project.

\section{References}

[1] DGR (Department of Groundwater Resources). 2009. Pilot Study and Experiment on Managed Aquifer Recharge Using Ponding System in the Lower North Region River Basin, Pitsanulok, Sukhothai, and Pichit Provinces. Progress report No. II. Groundwater Research Center, Khon Kaen University, Thailand.
[2] Asano, T. 1985. Artificial Recharge of Groundwater. Boston: Butterworth Publishers.

[3] Dillon, P. J. 2005. "Future Management of Aquifer Recharge.” Hydrogeology Journal 13 (1): 313-6.

[4] Dillon, P. J., Pavelic, P., Page, D., Beringen, H., and Ward, J. 2009. Managed Aquifer Recharge: An Introduction (Waterlines Report Series No. 13). Australia: The National Water Commission.

[5] Herman, B. 1996. "Issues in Artificial Recharge." Water Science Technology 33 (10-11): 381-90.

[6] Thai Meteorological Department. 2009. Thailand climate statistics year 1995-2009. Bangkok, Thailand.

[7] LDD (Land Development Department). 2000. Soil Series Map, Scale 1:50,000. Report on land use by province, Bangkok, Thailand.

[8] Gumma, M. K., Thenkabail, P. S., Fujii, H., and Namara, R. 2009. "Spatial Models for Selecting the Most Suitable Areas of Rice Cultivation in the Inland Valley Wetlands of Ghana Using Remote Sensing and Geographic Information Systems." Journal of Applied Remote Sensing 3 (June): 1-21.

[9] Nag, S. K. 2005. “Application of Lineament Density and Hydrogeomorphology to Delineate Groundwater Potential Zones of Baghmundi Block in Purulia District, West Bengal." Journal of the Indian Society of Remote Sensing 33 (4): 522-9.

[10] Saraf, A. K., and Choudhury, P. R. 1998. "Integrated Remote Sensing and GIS for Groundwater Exploration and Identification of Artificial Recharge Sites.” International Journal of Remote Sensing 19 (10): 1825-41.

[11] Das, D. 2000. Integrated Remote Sensing and Geographical Information System Based Approach Towards Groundwater Development Through Artificial Recharge in Hard-Rock Terrain. District, Tamilnadu. International Water Management Institute (IWMI), Research Impact.

[12] Ghayoumian, J., Mohseni, S. M., Feiznia, S., Nouri, B., and Malekian, A. 2007. "Application of GIS Techniques to Determine Areas Most Suitable for Artificial Groundwater Recharge in a Coastal Aquifer in Southern Iran.” Asian Earth Sciences 30 (2): 364-74.

[13] Brown, F. M. 2003. Boolean Reasoning: The Logic of Boolean Equations. 2nd ed. Mineola, NY: Dover Publications. 